\title{
Assessment of Nutritional Status of Primary School Children in Kallin District, Kafr El-Sheikh Governorate, Egypt
}

\author{
SHIMAA M. KOABAR, M.Sc.; SALWA A. ATLAM, M.D.; SALAH AL-DEEN SHEHAB, M.D. and \\ SAFYNAZ A. SHALABY, M.D. \\ The Department of Public Health \& Community Medicine, Faculty of Medicine, Tanta University, Tanta, Egypt
}

\begin{abstract}
Background: School health has been acknowledged as important since the beginning of 20 th century. Assessment of nutritional status is a major component of school health services.

Aim of the Study: This study was undertaken to assess the nutritional status of primary school children of Kallin city-Kafr Al-Sheikh governorate, Egypt.

Subjects and Methods: A cross-sectional study design was adopted. 2 in the rural section and 3 in the urban one with a total number of 3773 students. One urban and one rural school were chosen randomly from the governmental schools. A total of 433 pupils were included in the study. For each of the included children, socio-demographic data, dietary habits, food intake, physical examination for signs of nutritional deficiency were obtained and anthropometric measures such as (weight, height, mid upper-arm circumference and triceps skin fold thickness) were measured besides the $\mathrm{Hb}$ level which was taken from the health record of the child.
\end{abstract}

Results: The study results revealed that $29(6.7 \%)$ were wasted, $36(8.3 \%)$ were stunted, $6(1.3 \%)$ suffering from severe thinning, 4 (.9\%) were underweight, 137 (31.6\%) were overweight, and $56(13.1 \%)$ were obese. There were significant statistical relation between the BMI, residence of children and their socio-economic status, dietary habits, and food intake of the child.

Conclusion: From the results of the study we can conclude that over-nutrition and obesity were the prominent malnutrition problem among studied group while wasting and underweight was affecting a minimum percentage of their number.

Key Words: Nutritional status - Assessment - Primary school children.

\section{Introduction}

PUPILS in primary school represent an important social group in the society because they are more vulnerable to malnutrition; underweight or obesity [1].

Correspondence to: Dr. Shimaa M. Koabar,

The Department of Public Health \& Community Medicine, Faculty of Medicine, Tanta University, Tanta, Egypt
According to UNICEF (2011), more than 200 million school age children were stunted and underweight; about one billion school children will be growing up by 2020 with impaired physical and mental development thus directing attention towards obesity as a coming epidemic [2].

According to Egyptian National Nutrition Institute, in the year (2010-2014), malnutrition was still a major health problem in the Egyptian community among different age groups and socioeconomic classes [3-5]

Continuous nutritional assessment of the vulnerable groups especially children is very important for the evaluation of health and nutritional status besides the result of evaluation may be a base for future Planning, prevention and control programs of the nutritional problems [6-8]

\section{Study hypothesis:}

Malnutrition would be highly prevalent among primary school children (6-12 years) due to bad dietary habits in addition to inadequate dietary intake.

\section{Subjects and Methods}

Study design: A cross-sectional study was carried out among primary school children (6-12 years).

Study site and period: This study was carried out in primary schools of Kallin district; Kafr ElSheikh governorate and took place between February 2015 and completed by June 2017 .

\section{Sample size and technique:}

Stratified random sample method was used as follows: Kallin District was purposively chosen out of the 10 administrative districts of the Kafr 
Al-Sheikh governorate because of easy feasibility to the researcher. The educational administration of Kallin city includes 5 primary governmental schools; 2 rural and 3 urban with a total number of 3773 pupils. Two school were chosen randomly (one from rural and one from urban areas). The total number of pupils in the chosen rural school was 561 and in urban school was 674 during the scholastic year 2015/2016.

Each school has (12 classes); two classes in each grade. The sample was collected, one class from each grade (the first up to the six grade). To fulfill the required sample, the total number of studied children in the initial study was 480 pupils. After completion of the study, the total number of included pupils were 433 pupil with total response rate $89 \%$ (80\% response rate in rural schools and $98 \%$ response rate in urban schools).

The data from 193 rural and 240 urban pupils were completed and subjected to statistical analysis.

Inclusion criteria: Primary school children (612 years old) were included in this study.

Exclusion criteria: Children less than 6 years or more than 12 years old, those who were suffering from chronic diseases that may affect nutritional status e.g. heart disease, diabetes mellitus and bronchial asthma, and refusal of parents to participate.

Study tools and data collection technique: Data was collected through a direct interview with older children and through examining the health record of them. While young children were sent to their parents to fill in the questionnaire sheet with them, with the co-operation of their teacher, also through direct personal communication through telephone and/or home visits.

\section{A Pre designed questionnaire sheet containing data regarding:}

- Socio-demographic data: Which include age, sex, scholastic year, residence, family income, number of family members, number of rooms, birth order, father's and mother's education and occupation.

- Medical history: To exclude children with chronic disease.

- Assesment of nutritional status through:

- Anthropometry: Which include:

A- Weight measurement: Weight was measured to the nearest $0.1 \mathrm{~kg}(100 \mathrm{gm})$ using an electronic scale with children wearing light clothing and without shoes after checking the scale for accuracy and the result had been compared to that of WHO reference values $[\mathbf{9 , 1 0 ]}$.

B- Height measurement: Children's' heights were measured using a wooden stadiometer placed on a flat surface. The child stood on the basal part of the device with feet together (without shoes). The shoulders, the buttocks, and the heels had to touch the vertical measuring board. A child standing with his eyes in the horizontal plane, his height was measured to the nearest $1 \mathrm{~cm}$. and the result was classified into (normal, short, and tall) according to the growth chart and the result had been compared to that of WHO reference values $[9,10]$

\section{C-Calculating Body Mass Index (BMI) by using the equation:}

$\mathrm{BMI}=$ Weight in kilograms/height in meters squared and the result was classified into (normalsever thinning-underweight-overweight and obese) according to BMI children growth chart (Appendix 1) and the result had been compared to that of WHO reference values [10,11].

D-Mid- Upper Arm Circumference: Mid-Upper Arm Circumference (MUAC) was recorded with the help of flexible non-stretchable plastic measuring tape to the nearest $0.1 \mathrm{~cm}$ at the mid-point between the tip of the shoulder and the tip of the elbow (olecranon process and the acromion process) on the left upper arm while the arm is hanging down the side of the body and relaxed. And the reading was taken which was classified into (normal, above normal, below normal) as interpretation of the result, which compared with CDC standard values [12].

E- Skin Fold: Triceps skin fold measurement was done to assess subcutaneous body fat. Along the midline on the back of the triceps muscle of the right arm, determine the mid-point between the tip of the shoulder and the tip of the elbow (olecranon process and the acromion process. Pinch the skin so that the fold is running vertically. Grab the skin with the thumb and forefinger about 0.5 inches from the measurement site following the natural fold of the skin. Lift the skin up from the muscle, apply the calipers and wait for 4 seconds before reading the calipers. Fat is compressible, so reading the scale before or after the 4-sec delay may affect the results.

And the reading was taken which was classified into (normal, above normal, below normal) as interpretation of the result, which compared with CDC standard values [12] 
- Clinical examination searching for physical signs of nutrient deficiency: Which includes changes in hair, eye, teeth, face, lips, gums, skin.... if there is any signs denoting nutrient deficiency.

- Assessment of food intake: It was assessed by food frequency questionnaire. Depending on the common food groups [13]

- Assessment of dietary habits: Especially regarding the number of meals, snacks types and formseating between meals-consumption of fast food, carbonated beverages,coffee, and tea.

- Laboratory investigations: Reviewing the school students' health records, to collect data regards hemoglobin percentage (HB \%) and results of stool analysis for parasitic infestation. Classification of anemia was done based on WHO criteria [14] .

\section{Ethical consideration:}

The protocol was approved from the Ethical Committee of the Faculty of Medicine, Tanta University. Then from the administrator of the educational district, to which it belongs. Written consent was obtained from parents before starting the data collection by sending it through their children with a brief explanation about the study and the nature of the required data. Data was collected anonymously. Confidentiality and privacy was guaranteed during the whole period of the study.

\section{Statistical analysis:}

The questionnaire and data collected were filled, a code sheet was developed; sorting, and tabulation and analysis of data were performed by using SPSS-V21. Continuous variables are summarized in the mean, $\mathrm{SD}$, and for quantitative variables, summarized by number and percentage for qualitative variables.

\section{Results}

Distribution of the studied pupils according to socio-demographic data in relation to residence (Table 1):

A significant association was found between the residence of the pupils and all items (fathers' educational level, mother educational level, father occupation, mother occupation, family income) except sex and family size.

Table (1): Distribution of the studied pupils according to socio-demographic data in relation to residence.

\begin{tabular}{|c|c|c|c|c|c|c|c|c|}
\hline \multirow{2}{*}{ Characteristics } & \multicolumn{2}{|c|}{ Urban school (240) } & \multicolumn{2}{|c|}{ Rural school (193) } & \multicolumn{2}{|c|}{ Total } & \multirow{2}{*}{$\left(\mathrm{X}^{2}\right.$ test $)$} & \multirow{2}{*}{ ( $p$-value) } \\
\hline & No. & $\%$ & No. & $\%$ & No. & $\%$ & & \\
\hline \multicolumn{9}{|l|}{ Sex: } \\
\hline Male & 145 & 60.4 & 104 & 53.9 & 249 & 57.5 & \multirow{2}{*}{1.86} & \multirow[t]{2}{*}{.204} \\
\hline Female & 95 & 39.6 & 89 & 46.1 & 184 & 42.5 & & \\
\hline \multicolumn{9}{|l|}{ Father educational level: } \\
\hline Illiterate & 1 & .4 & 16 & 8.3 & 17 & 3.9 & \multirow[t]{4}{*}{168.1} & \multirow[t]{4}{*}{$.005 *$} \\
\hline Primary \& preparatory & 4 & 1.7 & 38 & 19.7 & 42 & 9.7 & & \\
\hline Secondary \& diploma & 64 & 26.7 & 117 & 60.6 & 181 & 41.8 & & \\
\hline University or higher & 171 & 71.3 & 22 & 11.4 & 193 & 44.6 & & \\
\hline \multicolumn{9}{|l|}{ Mother educational level: } \\
\hline Illiterate & 1 & .4 & 24 & 12.4 & 25 & 5.8 & \multirow{4}{*}{180.9} & \multirow[t]{4}{*}{$.005 *$} \\
\hline Primary \& preparatory & 4 & 1.7 & 42 & 21.8 & 46 & 10.6 & & \\
\hline Secondary \& diploma & 65 & 27.1 & 108 & 56.0 & 173 & 40 & & \\
\hline University or higher & 170 & 70.8 & 19 & 9.8 & 189 & 43.6 & & \\
\hline \multicolumn{9}{|l|}{ Father occupation: } \\
\hline Non skilled & 0 & 0 & 8 & 4.1 & 8 & 1.8 & \multirow{4}{*}{77.4} & \multirow{4}{*}{$.005 *$} \\
\hline Skilled & 13 & 5.4 & 68 & 35.2 & 81 & 18.7 & & \\
\hline Employee & 127 & 52.9 & 58 & 30.1 & 185 & 42.7 & & \\
\hline Professional & 100 & 41.7 & 59 & 30.6 & 159 & 36.8 & & \\
\hline \multicolumn{9}{|l|}{ Mother occupation: } \\
\hline Employee & 127 & 52.9 & 6 & 3.1 & 300 & 69.3 & \multirow{2}{*}{124.7} & \multirow{2}{*}{$.005 *$} \\
\hline Housewife & 113 & 47.1 & 187 & 96.9 & 133 & 30.7 & & \\
\hline \multicolumn{9}{|l|}{ Family income: } \\
\hline Not enough & 12 & 5 & 35 & 18.1 & 47 & 10.9 & \multirow[t]{3}{*}{193.1} & \multirow[t]{3}{*}{$.005 *$} \\
\hline Enough and not saving & 37 & 15.4 & 134 & 69.4 & 171 & 39.5 & & \\
\hline Enough and saving & 191 & 79.6 & 24 & 12.4 & 215 & 49.6 & & \\
\hline \multicolumn{9}{|l|}{ Family size: } \\
\hline$<5$ & 80 & 33.3 & 12 & 6.2 & 92 & 21.2 & \multirow[t]{2}{*}{11.1} & \multirow[t]{2}{*}{.17} \\
\hline$>=5$ & 160 & 66.7 & 181 & 93.7 & 341 & 78.8 & & \\
\hline
\end{tabular}

\footnotetext{
* Significant ( $p$-value).
} 
Relationship between socio-demographic characteristics of the child and their nutritional status (Table 2):

A significant association was found between the nutritional status of the pupils and all items of socio-demographic data (sex, residence, family income, fathers' educational level, mother educational level, father occupation, mother occupation, age) except family size. Where obesity is more found among highly educated parents, governmental employee fathers, and housewives.

Table (2): Relation between socio-demographic characteristics of the child and their nutritional status.

\begin{tabular}{|c|c|c|c|c|c|c|c|c|c|}
\hline \multirow{2}{*}{ Characteristics } & \multicolumn{2}{|c|}{ Normal (230) } & \multicolumn{2}{|c|}{ Over-nutrition (193) } & \multicolumn{2}{|c|}{ Under-nutrition (10) } & \multicolumn{2}{|c|}{ Total } & \multirow{2}{*}{$\frac{\mathrm{X}^{2}}{p \text {-value }}$} \\
\hline & No. & $\%$ & No. & $\%$ & No. & $\%$ & No. & $\%$ & \\
\hline \multicolumn{10}{|l|}{ Sex: } \\
\hline Male & 116 & 46.6 & 125 & 50.2 & 8 & 3.2 & 249 & 57.5 & 10.9 \\
\hline Female & 114 & 62.0 & 68 & 37.0 & 2 & 1.1 & 184 & 42.5 & $.004 *$ \\
\hline \multicolumn{10}{|l|}{ Residency: } \\
\hline Urban & 93 & 38.8 & 147 & 61.3 & 0 & 0.0 & 240 & 55.4 & 66.9 \\
\hline Rural & 137 & 71.0 & 46 & 23.8 & 10 & 5.2 & 193 & 44.6 & $.005 *$ \\
\hline \multicolumn{10}{|l|}{ Father educational level: } \\
\hline Illiterate & 11 & 64.7 & 6 & 35.3 & 0 & 0.0 & 17 & 3.9 & 32.3 \\
\hline Primary \& preparatory & 26 & 61.9 & 12 & 28.6 & 4 & 9.5 & 42 & 9.7 & $.005 *$ \\
\hline Secondary \& diploma & 110 & 60.8 & 65 & 35.9 & 6 & 3.3 & 181 & 41.8 & \\
\hline University or higher & 83 & 43.0 & 110 & 57.0 & 0 & 0.0 & 193 & 44.6 & \\
\hline \multicolumn{10}{|l|}{ Mother educational level: } \\
\hline Illiterate & 16 & 64.0 & 8 & 32.0 & 1 & 4.0 & 25 & 5.8 & 34.8 \\
\hline Primary \& preparatory & 30 & 65.2 & 11 & 23.9 & 5 & 10.9 & 46 & 10.6 & $.005 *$ \\
\hline Secondary \& diploma & 102 & 59.0 & 67 & 38.7 & 4 & 2.3 & 173 & 40 & \\
\hline University or higher & 82 & 43.4 & 107 & 56.6 & 0 & 0.0 & 189 & 43.6 & \\
\hline \multicolumn{10}{|l|}{ Father occupation: } \\
\hline Non skilled & 7 & 87.5 & 0 & 0.0 & 1 & 12.5 & 8 & 1.8 & 32.0 \\
\hline Skilled & 52 & 64.2 & 23 & 28.4 & 6 & 7.4 & 81 & 18.7 & $.005 *$ \\
\hline Employee & 84 & 45.4 & 100 & 54.1 & 1 & 0.5 & 185 & 42.7 & \\
\hline Professional & 87 & 54.7 & 70 & 44.0 & 2 & 1.3 & 159 & 36.8 & \\
\hline \multicolumn{10}{|l|}{ Mother occupation: } \\
\hline Employee & 175 & 58.3 & 115 & 38.3 & 10 & 3.3 & 300 & 69.3 & 17.9 \\
\hline Housewife & 55 & 41.4 & 78 & 58.6 & 0 & 0.0 & 133 & 30.7 & $.005 *$ \\
\hline \multicolumn{10}{|l|}{ Family income: } \\
\hline Not enough & 31 & 3.2 & 14 & 29.8 & 2 & 4.3 & 47 & 10.9 & 44.98 \\
\hline Enough and not saving & 114 & 66.7 & 50 & 29.2 & 7 & 4.1 & 171 & 39.5 & $.005 *$ \\
\hline Enough and saving & 85 & 39.5 & 129 & 60.0 & 1 & 0.5 & 215 & 49.6 & \\
\hline \multicolumn{10}{|l|}{ Family size: } \\
\hline$<5$ & 50 & 54.3 & 40 & 43.5 & 2 & 2.2 & 92 & 21.2 & .074 \\
\hline$>=5$ & 180 & 52.8 & 153 & 44.9 & 8 & 2.3 & 341 & 78.8 & .964 \\
\hline
\end{tabular}

* Significant ( $p$-value).

Distribution of the studied pupils according to their anthropometric measurements and residence (Table 3) (Figs. 1,2):

A significant association was found between the residence of the pupils and all items of the table. Concerning weight, $14.5 \%$ were underweight among rural pupils compared to $4 \%$ underweight among urban pupils. As regards to height, $8.3 \%$ were stunted where only $15.5 \%$ were short in rural children compared to only $2.5 \%$ in unbans. Whereas, $1.2 \%$ were tall (above normal). Regarding BMI, about one third $(31.6 \%)$, were overweight and
$13.1 \%$ were obese, where $38.8 \%$ of urban pupils were overweight and $22.4 \%$ were obese compared to $22.7 \%$ and $1.3 \%$ respectively among rural children. Only $0.9 \%$ were underweight and $1.3 \%$ were wasted, where $2 \%$ of rural children were underweight, and $3.1 \%$ were wasted while no one of the urban pupils were underweight nor wasted. As regard to mid-upper arm circumference, the majority of pupils (85.9\%) had normal mid upper-arm circumference, while $12.5 \%$ and $1.2 \%$ were below and above normal standards respectively, where only $20.2 \%$ of the rural pupils were below normal values compared to $7.1 \%$ in urban one and only 
$1.7 \%$ of the urban pupils had circumference above normal values, compared to $0.5 \%$ in rural one. Concerning triceps skinfold thickness (TSF thickness), it was above the normal standards in about a quarter $(24.2 \%)$ of them. Where $37.1 \%$ of urban students had a TSF thickness above normal values, and none of the urban and rural pupils had a thickness below normal values.

Table (3): Distribution of the studied pupils according to their anthropometric measurements and residence.

\begin{tabular}{|c|c|c|c|c|c|c|c|}
\hline \multirow[t]{2}{*}{ Characteristics } & \multicolumn{2}{|c|}{$\begin{array}{l}\text { Urban school } \\
\text { N (240) }\end{array}$} & \multicolumn{2}{|c|}{$\begin{array}{l}\text { Rural school } \\
\text { N (193) }\end{array}$} & \multicolumn{2}{|c|}{ Total } & \multirow{2}{*}{$\frac{\left(\mathrm{X}^{2} \text { test }\right)}{p \text {-value }}$} \\
\hline & No. & $\%$ & No. & $\%$ & No. & $\%$ & \\
\hline \multicolumn{8}{|l|}{ Weight for age: } \\
\hline Normal & 197 & 82.1 & 165 & 85.5 & 362 & 83.6 & 65.63 \\
\hline Underweight & 1 & .4 & 28 & 14.5 & 29 & 6.7 & $.005^{*}$ \\
\hline Overweight & 42 & 17.5 & 0 & 0 & 42 & 9.7 & \\
\hline \multicolumn{8}{|l|}{ Height for age: } \\
\hline Normal & 229 & 95.4 & 163 & 84.5 & 392 & 90.5 & 27.33 \\
\hline Short & 6 & 2.5 & 30 & 15.5 & 36 & 8.3 & $.005^{*}$ \\
\hline Tall & 5 & 2.1 & 0 & 0 & 5 & 1.2 & \\
\hline \multicolumn{8}{|l|}{ BMI: } \\
\hline Normal & 93 & 38.8 & 137 & 70.9 & 230 & 53.1 & 388.4 \\
\hline Sever thinning & 0 & 0 & 6 & 3.1 & 6 & 1.3 & \\
\hline Under-weight & 0 & 0 & 4 & 2 & 4 & .9 & \\
\hline Overweight & 93 & 38.8 & 44 & 22.7 & 137 & 31.6 & $.005^{*}$ \\
\hline Obese & 54 & 22.4 & 2 & 1.3 & 56 & 13.1 & \\
\hline \multicolumn{8}{|c|}{ Mid upper-arm circumference: } \\
\hline Below normal & 17 & 7.1 & 39 & 20.2 & 56 & 12.9 & 17.94 \\
\hline Normal & 219 & 91.2 & 153 & 79.3 & 372 & 85.9 & $.005^{*}$ \\
\hline Above normal & 4 & 1.7 & 1 & .5 & 5 & 1.2 & \\
\hline \multicolumn{8}{|c|}{ Triceps skinfold thickness: } \\
\hline Normal & 151 & 62.9 & 177 & 91.7 & 328 & 75.8 & 48.28 \\
\hline Above normal & 89 & 37.1 & 16 & 8.3 & 105 & 24.2 & $.005^{*}$ \\
\hline
\end{tabular}

* Significant ( $p$-value).

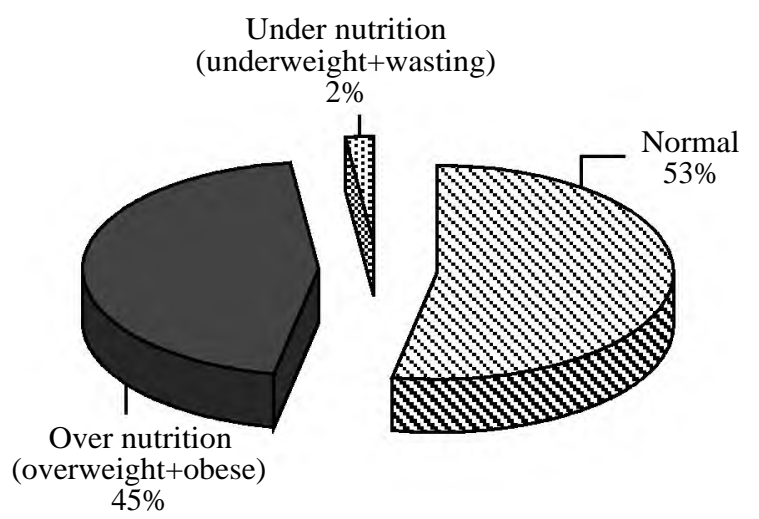

Fig. (1): Distribution of studied pupils according to their weight status.

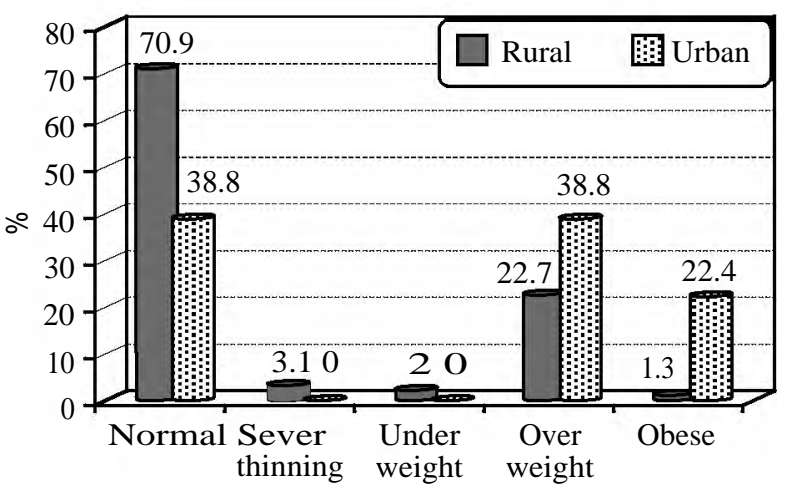

Fig. (2): Distribution of studied pupils according to BMI. 
Distribution of the studied pupils according to their dietary habits in relation to nutritional status (Table 4):

A significant association was found between the nutritional status of the pupils and these items (number of main meals, taking snacks, types of snacks, circumstances of eating food); While there was no significant association between the nutritional status of the pupils and the remaining items $p$-value $(0.437,0.311,0.560$ respectively).
Distribution of the studied pupils according to their dietary habits in relation to residence (Table 5):

A significant association was found between residence of the pupils and these items (taking breakfast, taking snacks, form of snacks, place of eating food, circumstances of eating food) where rural pupils were better than urban pupils regarding their dietary habits. While there was no significant association between residence of the pupils and the remaining items (number of main meals, skipped meal and type of disliked food).

Table (4): Distribution of the studied pupils according to their dietary habits in relation to nutritional status.

\begin{tabular}{|c|c|c|c|c|c|c|c|c|c|}
\hline \multirow[t]{2}{*}{ Characteristics } & \multicolumn{2}{|c|}{$\begin{array}{l}\text { Normal } \\
230\end{array}$} & \multicolumn{2}{|c|}{$\begin{array}{l}\text { Over-nutrition } \\
193\end{array}$} & \multicolumn{2}{|c|}{$\begin{array}{l}\text { Under-nutrition } \\
10\end{array}$} & \multicolumn{2}{|c|}{$\begin{array}{l}\text { Total } \\
433\end{array}$} & \multirow{2}{*}{$\frac{\mathrm{X}^{2}}{p \text {-value }}$} \\
\hline & No. & $\%$ & No. & $\%$ & No. & $\%$ & No. & $\%$ & \\
\hline \multicolumn{10}{|l|}{ Number of main meals: } \\
\hline Two & 90 & 58.4 & 58 & 37.7 & 6 & 3.9 & 154 & 35.6 & 6.44 \\
\hline Three & 140 & 50.2 & 135 & 48.4 & 4 & 1.4 & 279 & 64.4 & $.040 *$ \\
\hline \multicolumn{10}{|l|}{ Taking breakfast daily: } \\
\hline Always & 33 & 55 & 27 & 45 & 0 & 0 & 60 & 13.9 & 1.66 \\
\hline Sometimes & 197 & 52.8 & 166 & 44.5 & 10 & 2.7 & 373 & 86.1 & .437 \\
\hline \multicolumn{10}{|l|}{ Skipped meal: } \\
\hline Breakfast & 115 & 52.3 & 96 & 43.6 & 9 & 4.1 & 220 & 50.8 & \\
\hline Launch & 2 & 100 & 0 & 0 & 0 & 0 & 2 & .5 & \\
\hline Dinner & 95 & 55.2 & 76 & 44.2 & 1 & 6 & 172 & 39.7 & .251 \\
\hline More than one meal & 7 & 50 & 7 & 50 & 0 & 0 & 14 & 3.2 & .311 \\
\hline None & 11 & 44.0 & 14 & 56 & 0 & 0 & 25 & 5.8 & \\
\hline \multicolumn{10}{|l|}{ Taking snacks: } \\
\hline Always & 8 & 42.1 & 11 & 57.9 & 0 & 0 & 19 & 4.4 & \\
\hline Sometimes & 197 & 52.0 & 177 & 46.7 & 5 & 1.3 & 379 & 87.5 & 34.1 \\
\hline Rarely/never & 25 & 71.4 & 14.3 & 5 & 14.3 & 5 & 35 & 8.1 & $.005 *$ \\
\hline \multicolumn{10}{|l|}{ Types of snacks: } \\
\hline Healthy snacks & 51 & 45.5 & 59 & 52.7 & 2 & 1.8 & 112 & 25.8 & 41.4 \\
\hline Unhealthy snacks & 179 & 55.8 & 134 & 41.7 & 8 & 2.5 & 321 & 74.1 & $.005 *$ \\
\hline \multicolumn{10}{|l|}{ Type of disliked food: } \\
\hline Milk & 50 & 54.9 & 39 & 42.9 & 2 & 2.2 & 91 & 21 & \\
\hline Meat & 20 & 57.1 & 15 & 42.9 & 0 & 0 & 35 & 8.1 & 6.79 \\
\hline Fish & 29 & 42.8 & 38 & 56.7 & 1 & 1.5 & 68 & 15.7 & .560 \\
\hline Cooked vegetables & 131 & 54.8 & 101 & 42.3 & 7 & 2.9 & 239 & 55.2 & \\
\hline \multicolumn{10}{|l|}{ Circumst-ances of eating food: } \\
\hline $\begin{array}{l}\text { Eating during studying, } \\
\text { watching TV and computer (alone) }\end{array}$ & 49 & 21.3 & 101 & 52.3 & 0 & 0 & 150 & 34.6 & 11.0 \\
\hline Outside with friends & 24 & 52.2 & 22 & 47.8 & 0 & 0 & 46 & 10.6 & $.026^{*}$ \\
\hline With family & 157 & 68.3 & 70 & 36.3 & 10 & 2.6 & 237 & 54.8 & \\
\hline
\end{tabular}

* Significant ( $p$-value). 
Table (5): Distribution of the studied pupils according to their dietary habits in relation to residence.

\begin{tabular}{|c|c|c|c|c|c|c|c|c|}
\hline \multirow[t]{2}{*}{ Characteristics } & \multicolumn{2}{|c|}{$\begin{array}{l}\text { Urban school } \\
\text { N (240) }\end{array}$} & \multicolumn{2}{|c|}{$\begin{array}{l}\text { Rural school } \\
\text { N (193) }\end{array}$} & \multicolumn{2}{|c|}{ Total } & \multirow[t]{2}{*}{$\left(\mathrm{X}^{2}\right.$ test $)$} & \multirow[t]{2}{*}{$p$-value } \\
\hline & No. & $\%$ & No. & $\%$ & No. & $\%$ & & \\
\hline \multicolumn{9}{|l|}{ Number of main meals: } \\
\hline Two & 89 & 37.1 & 65 & 33.7 & 154 & 35.6 & .541 & .462 \\
\hline Three & 151 & 62.9 & 128 & 66.3 & 279 & 64.4 & & \\
\hline \multicolumn{9}{|l|}{ Taking breakfast daily: } \\
\hline Always & 17 & 7.1 & 43 & 22.3 & 60 & 13.9 & 20.69 & $.005^{*}$ \\
\hline Sometimes & 223 & 96.9 & 150 & 77.7 & 373 & 86.1 & & \\
\hline \multicolumn{9}{|l|}{ Skipped meal: } \\
\hline Breakfast & 110 & 45.8 & 110 & 57.0 & 220 & 50.8 & 7.99 & .065 \\
\hline Launch & 1 & .4 & 1 & .5 & 2 & .5 & & \\
\hline Dinner & 105 & 43.8 & 67 & 34.7 & 172 & 39.7 & & \\
\hline More than one meal & 11 & 4.6 & 3 & 1.6 & 14 & 3.2 & & \\
\hline None & 13 & 5.4 & 12 & 6.2 & 25 & 5.8 & & \\
\hline \multicolumn{9}{|l|}{ Taking snacks: } \\
\hline Always & 11 & 4.6 & 8 & 4.1 & 19 & 4.4 & 11.12 & $.004 *$ \\
\hline Sometimes & 219 & 91.3 & 160 & 82.9 & 379 & 87.5 & & \\
\hline Rarely/never & 10 & 4.2 & 25 & 13.0 & 35 & 8.1 & & \\
\hline \multicolumn{9}{|l|}{ Types of snacks: } \\
\hline Healthy snacks & 66 & 58.9 & 46 & 41.1 & 112 & 25.9 & 49.07 & $.005^{*}$ \\
\hline Unhealthy snacks & 174 & 54.2 & 147 & 45.8 & 321 & 74.1 & & \\
\hline \multicolumn{9}{|l|}{ Type of disliked food: } \\
\hline Milk & 49 & 20.4 & 42 & 21.8 & 91 & 21 & 5.67 & .200 \\
\hline Meat & 14 & 5.8 & 21 & 10.9 & 35 & 8.1 & & \\
\hline Fish & 37 & 15.4 & 31 & 16 & 68 & 15.7 & & \\
\hline Cooked vegetables & 140 & 58.3 & 99 & 51.3 & 239 & 55.2 & & \\
\hline \multicolumn{9}{|l|}{ Circumstances of eating food: } \\
\hline $\begin{array}{l}\text { Eating during studying, } \\
\text { watching TV and computer (alone) }\end{array}$ & 100 & 41.7 & 50 & 25.9 & 150 & 34.6 & 6.42 & $.023 *$ \\
\hline Outside with friends & 33 & 13.8 & 13 & 6.7 & 46 & 10.6 & & \\
\hline With family & 107 & 24.7 & 130 & 67.4 & 237 & 54.8 & & \\
\hline
\end{tabular}

* Significant ( $p$-value).

Distribution of studied pupils according to stool analysis (Fig. 3):

A significant association was found between parasitic infestation and nutritional status of the pupils. $p$-value $(.012 *)$.

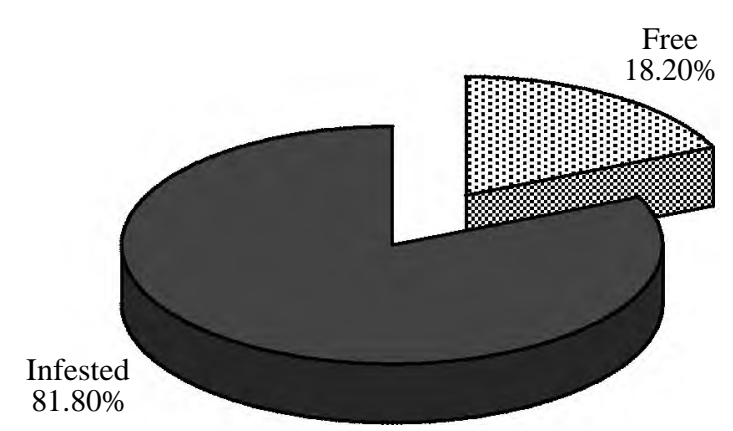

Fig. (3): Distribution of studied pupils according to stool analysis.
Distribution of studied pupils according to HB\% (Fig. 4):

A significant association was found between BMI of the pupils and HB \%. p-value (.005*).

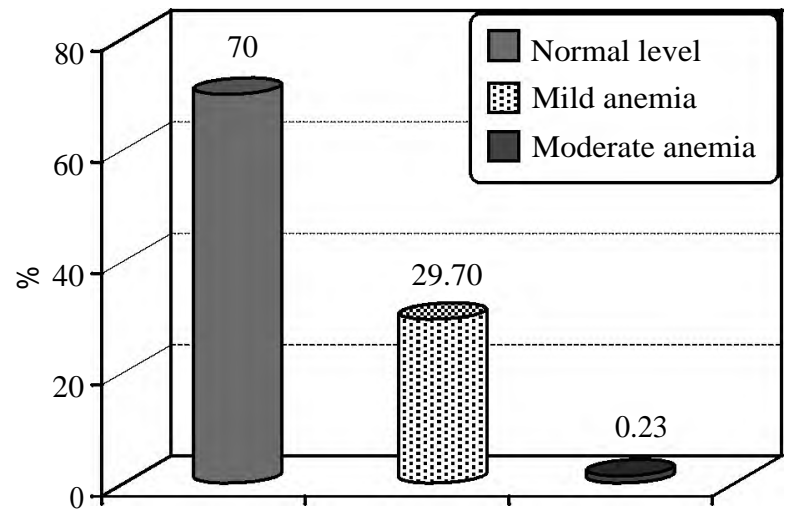

Fig. (4): Distribution of studied pupils according to HB\%. 


\section{Discussion}

\section{Prevalence of malnutrition among studied children:}

The present work revealed a higher prevalence of over-nutrition and lower prevalence of undernutrition among the studied sample. The prevalence of overweight and obesity in this study was higher than that reported in previous Egyptian studies where Hafez et al. [15], Hassan et al. [16] in Giza, Ghalli [17], El-Masry [18], also, Elsayed et al. [19], El-Masry [20], and El-Shafie and his colleagues $[\mathbf{2 1 , 2 2 , 2 3 ]}$ in Dakahlia; Besides Matijasevich et al. [24]in UK and Brazil who reported their prevalence as $(8.7 \%$ and $4 \%)$ respectively. These results were also in agreement with those of Pena Reyes et al. [25]in Turkey who reported higher values of height, weight, BMI in urban boys than the rural boys. However, Singh et al. [26], Tsimeas et al. [27], found no significant differences in body mass index between urban and rural Greek children. Whereas Johnson et al. [28] (2015), Emam et al. [29] found that residence in rural areas was associated with higher prevalence of childhood obesity, compared to children living in urban areas.

The study reported that the urban children showed higher measures as compared to rural children regarding mid-upper arm circumference and triceps skin fold thickness that was in line with Singh et al. [26], and Tsimeas et al. [27], on Greek children in which they found no differences were reported between urban and rural boys with regard to the body compositions. In this study, the prevalence of underweight (low weight for age) was (6.7\%), where $14.5 \%$ were from rural school compared to only $0.4 \%$ in unbans, regarding BMI, only $0.9 \%$ were underweight and $1.3 \%$ were wasted (low weight for height), where $2 \%$ of rural children were underweight, and $3.1 \%$ were wasted compared with the urban pupils being neither underweight nor wasted, stunting (low height for age) was $(8.3 \%)$. Where $15.5 \%$ were from rural school compared to only $2.5 \%$ in urbans. Also, $2 \%$ of rural children were underweight, and $5.1 \%$ were wasted while none of the urban students were wasted. This comes with El-Masry et al. [20], Elsayed et al. [30], in Zagazig City, and Goon et al. [31], in Makurdi, Nigeria, found that (43.4\% and 52.7\%) were found to be underweight and stunting respectively. The differences in the reported prevalence rates might be due to biologic, environmental, and socioeconomic variations in each community.

Relation between socio-demographic data and residence:

The present result shows a higher anthropometric measures among urban students than rural students. This can be explained on there was a significant association between the nutritional status of the pupils and those items (fathers' educational level, mother educational level, father occupation, mother occupation, family income), also it has been explained by Bahbah et al. (2015), in Menoufia Governorate; Menouf district showed that dietary variation between urban and rural children could be attributed to excessive intake of snacks between meals as processed meat, processed cheese, rice, artificial juices, and carbonated beverages, as well as the longer duration of sitting when playing video and computer games and influences from advertisements on fatty food. All those behaviors are mostly related to families with higher social class [32]. This had been proved also by Amin [33], and Abuzaid [34] found that urban pupils parent's educational level was higher as compared to parents of rural pupils. Similarly, Nabag [35] , and Perveen et al. [36] (2016), found that the level of illiteracy among parents of rural school children was higher compared to the urban ones. El-Masry [18], found that childhood obesity and overweight were more prominent among children with non-working housewives mothers and highly educated fathers (college or above). Elsayed et al. [30] and Hassan [16] found that childhood obesity and overweight were more prominent in urban than rural areas, among children with nonworking housewife mothers and highly educated fathers (college or above). In contrary to the present study, El-Masry [18], found that childhood obesity and overweight were more prominent in rural than urban areas. Also, Talat and El-Shahat [37] in Urban Sharkia Governorate; Egypt; they concluded that risk factors for overweight and obesity were significantly higher among children with low educated parents. This was attributed to wrong believes among low educated parents regarding obesity as a good sign of health and so they prefer to introduce high caloric foods to their children. The concurrent result revealed a significant association between obesity and non-working housewife mothers; where obesity occurs due to unhealthy eating habits and sedentary lifestyle rather than working status of the mother. This was in agreement with Güven et al. [38] in Turkey, while Hawkins et al. [39], and Thibault et al. [40] found a significant association between obesity and working status of the mother as the child is more likely to be overweight if his mother works more hours per week during childhood that prevents young children's access to healthy foods and physical activity.

\section{$B M I$, residence and dietary habits:}

In this study $94.2 \%$ of the studied sample skipping meals, $50.8 \%$ skipping breakfast $39.7 \%$ skip- 
ping dinner. $22.3 \%$ of rural students always took breakfast daily compared to $7.1 \%$ of urban students, regarding snack intake, $91.9 \%$ taking snacks, $47.1 \%$ take unhealthy snacks, where it was more prevalent in urban students than rural one $(54.2 \%$ \& $45.8 \%$ respectively), also $41.7 \%$ overweight pupils taking unhealthy snacks, $55.2 \%$ of studied pupils dislike cooked vegetables compared to $21 \%$ dislike milk, $15.7 \%$ dislike fish, and $8.1 \%$ dislike meat, $25.9 \%$ of rural children ate during watching T.V compared to $41.7 \%$ of urban pupils. This was in agreement with National Institute of Nutrition (NIN), Egypt [41] (2003-2004), Amini, [42] (2014), and Handa et al. [43] (2008), in India, also Zaki et al. [44], reported that one of the main reasons for obesity in children was lacking of physical activity, Also, she showed that obese children significantly spent more time watching television and less time exercising than normal weight children. Also, this was in line with a previous report from the WHO reported that children had an increase in body fat often associated with irregular meals, changing food habits, and inactivity [45]. The current findings regarding snack consumption amongst rural and urban children are supported by the study of Aziz \& Devi [46], showed that instant sweet and chocolate are more consumed by urban children than rural children. Abu Zaid [34] (2012), Perveen et al. [36] and Davis et al. [47] reported that rural pupils take breakfast daily more than urban pupils and the trend of skipping breakfast is more common amongst urban school children than rural students, and also showed that urban pupils were more influenced by TV than rural ones.

\section{Conclusion:}

Over nutrition and obesity were the prominent figure of malnutrition among studied group when compared with undernutrition. Also anemia was recorded among considerable percentage of the studied pupils especially among overweight that was attributed to dietary quality rather than quantity, due to bad dietary habits such as excessive CHO, snacks consumption, wide spread of fast food in addition to lack of protein, fruit and vegetables intake, eating in front of TV, computers in addition to meal skipping especially breakfast and an increase in soft drink and beverages intake. Besides parasitic infections was prevalent among the majority of children and was significantly associated with malnutrition. Nutritional status was strongly associated with life style, socio-demographic data, food intake and dietary habits.

\section{Recommendation:}

Continuous assessment of nutritional status of school children is important for regular check of the health status of these sectors of the community. Basic facts in nutrition and healthy eating practices should be included in the curriculum of all school stages. In addition to nutritional education programs should be directed to teachers, school children and their parents especially regarding nutritional requirements and healthy feeding practice and how to eat a balanced diet and impact of bad feeding practice. Also recommending that efforts should be directed towards increased physical activity inside \& outside schools besides the time for physical exercise should be mandatory in school schedule with giving special interests to playgrounds. Attention should be paid to school feeding program as a chance to nutritional education for a child besides supplying considerable amounts of energy requirements for children. Also school canteen should be observed to supply healthy food only.

\section{References}

1- BUNDY D., BURBANO C., GROSH M., GELLI A., JUKES M. and DRAKE L.: Rethinking School Feeding: Social Safety Nets, Child Development and the Education Sector. The International Bank for Reconstruction and Development. The World Bank, Washington DC. http://dx.doi.org/10.1596/978-0-8213-7974-5, 2009.

2- UNICEF: Levels and Trends in Child Mortality. Estimates Developed by the UN Inter-Agency Group for Child Mortality Estimation, 2011.

3- World Health Organization: Country Cooperation Strategy for WHO and Egypt 2010-2014. WHO Regional Office for the Eastern Mediterranean, Cairo. http://www.who.int/ countryfocus/cooperation_strategy/ccs_egy_en.pdf, 2010.

4- EL-ZANATY F. and WAY A.: Egypt Demographic and Health Survey (2008). Demographic and Health Surveys, Ministry of Health, Cairo, 2009.

5- EL-ZANATY F. and WAY A.: Egypt Demographic andHealth Survey 2014. Demographic and Health Surveys, Ministry of Health, Cairo, 2015.

6- ABDELAZIZ S.B., YOUSSEF M.R.L., SEDRAK A.S and LABIB J.R.: "Nutritional Status and Dietary Habits of School Children in Beni-Suef Governorate, Egypt". Food and Nutrition Sciences, 6: 54-63. 21, 2015.

7- SYED S. and RAO R.: "Factors influencing nutritional status of school children in an urban slum of Hyderabad, India". Int. J. Contemp Pediatr, 2015; 2 (4): 335-339. 23, 2015.

8- KHAYRI O.H., MUNEER E.S., AHMED B.S., et al.: Assessment of the Nutritional Status of Sudanese Primary School Pupils in Riyadh City, Kingdom of Saudi Arabia. J. Immigrant Minority Health, 18: 28-33, 2016.

9- LEE R.D. and NIEMAN D.C.: Nutritional Assessment. Oxford, UK: Brown and Benchmark, 1993.

10- World Health Organization (WHO): WHO Child Growth Standards: Length/height-for-age, Weight-for-age, Weightfor-length, Weight-for-height and Body mass index-forage: Methods and Development. Geneva: World Health Organization, 2006. In De Onis M., Onyango A.W., Borghi 
E., Farza C., Yang H. 2006. Comparison of the World Health Organization (WHO) child Growth Standards and the National Center for Health Statistics/WHO international growth reference: implications for the child health programmes. Public Health Nutrition, 9 (7): 942-947, 2007.

11- WHO: The International Classification of Adult Underweight, Overweight and Obesity according to BMI. http://apps.who. int/bmi/index.j sp?introPage=intro_3.html, 2008.

12-Us department of health and human services, center for disease control and prevention, national center for health statistics: "Anthropometric Reference Data for Children and Adults: United States, 2007-2010". Vital and Health Statistics, 11 (252): 1-48, 2012.

13- CASCADE J.E., et al.: food frequency questionnaire-a review of their design,validation, utilization. Nutrition Research Review, 17: 5-23, 2004.

14- WHO: Hemoglobin concentrations for the diagnosis of anemia and assessment of severity. Vitamin and Mineral Nutrition Information System. Geneva: 2011. World Health Organization (WHO/NMH/NHD/ MNM/11.1), 2011.

15- HAFEZ A.S., EI-AWADY M.Y. and HASSAN N.E.: Obesity profile among primary school children in Cairo. Egypt J. Commun. Med., 18: 99-119, 2000.

16- HASSAN E.N., et al.: Influence of Parental and Some Demographic Characteristics on Overweight/Obesity Status among a Sample of Egyptian Children Open Access Maced J. Med. Sci., 4 (3): 342-347, 2016.

17- GHALLI I., SALAH N., HUSSIEN F., ERFAN M., ELRUBY M., MAZEN I., et al.: Egyptian growth curves 2002 for infants, children and adolescents. Recently published in:. In: Sartorio A., Buckler J.M.H., Marazzi N., editors. Crescerenelmondo. Ferring Publisher, 2008.

18- EL-MASRY S.A.: Nutritional assessment of Egyptian children. Egypt Med. J. NRC, 6 (2): 40-49, 2007.

19- ELSAYED H.H., KHAIRY S., ABD EL-RAHMAN MOHAMED K. and AFIFIEFFAT A.: Assessment of Nutrition of Obese Primary Schools Children in Urban and Rural Area in El Bihera Governorate- Egypt.Egyptian Journal of Hospital Medicine, 3859-81, 2010.

20- EL-MASRY A.S., et al.: Nutritional Status among South Sinai Children using Anthropometric measures. Sci. Res., 8 (8): 4574-4580, 2012.

21- EL-SHAFIE M.A., BAHBAH M.H. and RANDA A.M.: Recent advances inpathophysiology and management of childhood obesity (Master essay). Menoufia: Faculty of Medicine Menoufia University, 2011.

22- BABAH M.H., HEGRAN H.H. and METWALY M.M.: Prevalence of obesity in primary school children living in Dakahlia governorate (El-Sinbellaween district) [Master thesis in pediatrics]. Menoufia: Faculty of Medicine, Menoufia University, 2012.

23- EL-SHAFIE A.M. and SLEEM A.A.: Prevalence of obesity in primary schoolchildren living in Dakahlia governorate (Mit-Ghamr State) [Master thesis in Pediatrics]. Menoufia: Faculty of Medicine, Menoufia University, 2013.

24- MATIJASEVICH A., GOLDING J., SMITH G.D., SANTOS I.S., BARROS A.J. and VICTORA C.G.: Differentials and income-related inequalities in maternal depression during the first two years after childbirth: Birth cohort studies from Brazil and the UK. Clinical Practice and Epidemiology in Mental Health, 5 (1): 12, 2009.

25- PENA REYES M.E., TAN S.K. and MALINA R.M. Urban-rural contrasts in the physical fitness of school children in Oaxaca, Mexico. American Journal of Human Biology, 15: 800-813, 2003.

26- SINGH K.M., SINGH M. and SINGH K.: Comparison of anthropometric measurements and body composition among the 12 years old rural and urban children. International Journal of Physiology, Nutrition and Physical Education, 2 (1): 262-265, 2017.

27- TSIMEAS P.D., TSIOKANOS A.L., KOUTEDAKIS Y., TSIGILIS N. and KELLIS S.: Does living in urban or rural settings affectaspects of physical fitness in children? An allometricapproach. British Journal of Sports Medicine, 39 (9): 671-674, 2005.

28- JOHNSON III J.A. and JOHNSON A.M.: Urban-rural differences in childhood and adolescent obesity in the United States: A systematic review and meta-analysis. Childhood Obesity, 11 (3): 233-241, 2015.

29- EMAM S., MOSTAFA R., WASSEF O., et al.: "Assessment of Nutritional Status of Some Primary School Children and Their Awareness in Slum Areas". Alexandria Journal of Pediatrics, 19 (1): 113-116, 2005.

30- ELSAYED H.Y., et al.: Comparative Study of Nutritional Status and Dietary Habits of Children from Public and Private Primary Schools in Zagazig City, Egypt IOSR Journal of Nursing and Health Science (IOSR-JNHS) eISSN: 2320-1959. p- ISSN: 2320-1940 Volume 3, Issue 1, Ver. I, (Nov. - Dec. 2013), PP 47-52, 2013.

31- GOON T.D., TORIOLA L.A., SHAW S.B., AMUSA O.L., MONYEKI A.M., AKINYEMI O. and ALABI A.O.: "anthropometrically determined the nutritional status of urban primary school children in Makurdi, Nigeria". BMC Public Health, 11: 769, 2011.

32- BAHBAH M.H., SLAMA E.S.I., RAMADAN A.E.M. and ABO ZEED M.A.: Prevalence of obesity and overweight in primary school children living in Menoufiaovernorate, Menouf district. Benha Med. J. [serial online], 32: 73-7, 2015.

33- AMIN T.T., ALI A. and KALIYADAN F.: Skin disorders among male primary school children in Al Hassa, Saudi Arabia: Prevalence and socio-demographic correlates-a comparison of urban and rural populations. Rural Remote Health, 11 (1): 1517, 2011.

34- ABUZAID OI.: Eating patterns and physical activity characteristics among urban and rural students in Saudi Arabia.Nutrition and Health Sciences Dissertation and Thesis. Retrieved from http://digitalcommons. . unl.edu/nutritiondiss/39, 2012.

35- NABAG F.O.: Comparative Study of Nutritional Status of Urban and Rural School Girl's Children Khartoum State, Sudan. Journal of Science and Technology, 12 (02): 60-68, 2011.

36- PERVEEN R., ASHIQ Z., NAZ S. and SIBT-E-ABBAS M.: Evaluation and comparison of dietary habits of rural and urban areas school children; A case study. Pakistan Journal of Food Sciences, 26 (1): 01-09.9, 2016. 
37- TALAT M.A. and EL SHAHAT E.: Prevalence of overweight and obesity among preparatory school adolescents in Urban Sharkia Governorate, Egypt. Egyptian Pediatric Association Gazette, 64 (1): 20-5, 2016.

38- GÜVEN A., ODACI H., OZGEN I.T. and BEK Y.: Effects of individual factors on adolescent obesity: Study in Turkey. Pediatr. Int., 50 (3): 356-62, 2008.

39- HAWKINS T. and COLE C.: Law, Millennium Cohort Study Child Health Group Maternal employment and early childhood overweight: Findings from UK Millennium Cohort Study. Int. J. Obes. (Lond), 32 (1): 30-38, 2008.

40- THIBAULT H., CONTRAND B., SAUBUSSE E., BAINE M. and MAURICE-TISON S.: Risk factors for overweight and obesity in French adolescents: Physicalactivity, sedentary behavior and parental characteristics. Nutrition, 26: 192-200, 2010.

41- National Institute of Nutrition: Differences in attentionconcentration, memory and school achievement of regular and irregular breakfast eaters and non eaters. Annual Report, 4: 27-30, 2003.

42- MARYAM A., MONIREH D.P., MITRA MORTEZA A., ANAHITA H. and MASOUD K.: Nutritional Assessment for Primary School Children in Tehran: An Evaluation of
Dietary Pattern with Emphasis on Snacks and Meals Consumption Int. J. Prev. Med., 5 (5): 611-616, 2014.

43- HANDA R., AHAMAD F., KESARI K.K. and PRASAD R.: Assessment of nutritional status of 7-10 years school going children of Allahabad district: A review. MiddleEast Journal of Scientific Research, 3 (3): 109-115, 2008.

44- ZAKI M.E., MOHAMED S.K. and EL-SALAM M.A. Risk factors for obesity among Egyptian children. Australian Journal of Basic and Applied Sciences, 5 (9): 10061011, 2011.

45- World Health Organization: Consideration of the evidence on childhood obesity for the Commission on Ending Childhood Obesity: Report of the ad hoc working group on science and evidence for ending childhood obesity, Geneva, Switzerland, 2016.

46-AZIZ M.F.A. and DEVI M.N.: Nutritional Status and Eating Practices Among Children Aged 4-6 Years Old in Selected Urban and Rural Kindergarten in Selangor, Malaysia. Asian J. Clin. Nutri., 4 (4): 116-131, 2012.

47-DAVIS A.M., BOLES R.E., JAMES R.L., SULLIVAN D.K., DONNELLY J.E., SWIRCZYNSKI D.L. and GOETZ J.: Health behaviors and weight status among urban and rural children. Rur. Remote Healt., 8 (2): 810 , 2008.

\section{تقييم الحالة الغذائية لتلاميذ المدارس الابتدائية

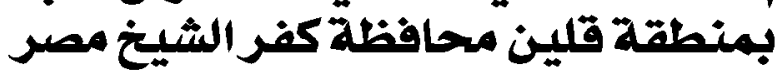

مقدمة: تم الاعتراف بأهمية الصحة المدرسية منذ بداية القرن العشرين. وتشكل الصالة التغنوية عنصراً رئيسياً فى الخدمات الصحية

الهدف: وقد أجريت هذه الدراسة لتقييم الحالة التفذوية لأطفال المدارس الابتدائية بمنطقة قلين محافظة كفر الشيخ.

الموضوعات والطرق: تم اعتماد تصميم دراسة مستعرضة. تم اختيار مدرستين حكوميتين ابتدائيتين (واحدة حضرية وواحدة حيث كان

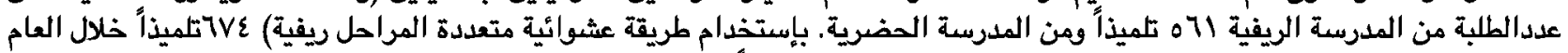

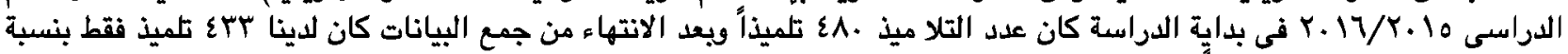

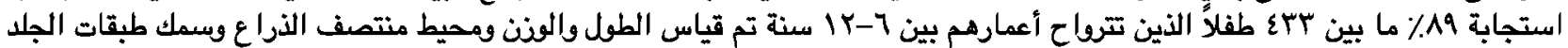

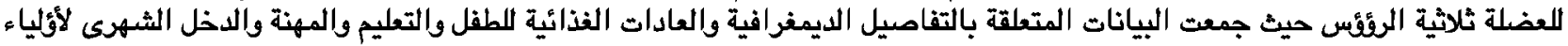

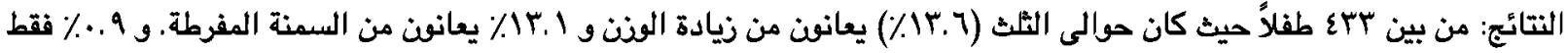

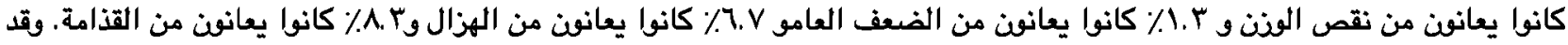

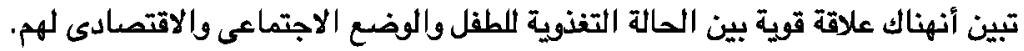

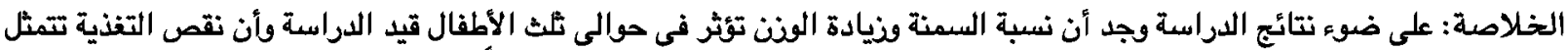

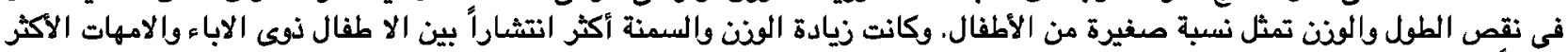
تعليماً وبين ربات البيوت مالمنت تمثل الامهات أكثر. فيرة 